\title{
KOMPARASI KINERJA MINI BUS BYSON DAN BUS MINI HIJAU JURUSAN SURABAYA - KRIAN BERBASIS PERSEPSI PENUNPANG
}

\author{
Achmad Rifai ${ }^{1)}$, A.A Sagung Alit Widyastuty ${ }^{2)}$ \\ 1,2Program Studi Perencanaan Wilayah dan Kota, Fakultas Teknik Sipil dan Perencanaan \\ Universitas PGRI Adi Buana Surabaya \\ Email : ${ }^{1}$ easycupz@gmail.com, 2tu.alitwidy@gmail.com
}

\begin{abstract}
Abstrak
Permasalahan angkutan umum di perkotaan yaitu kurangnya minat masyarakat untuk menggunakan jasa angkutan umum, dikarenakan masyarakat menghendaki adanya tingkat pelayanan yang cukup memadai yang meliputi waktu perjalanan, tarif, fasilitas keselamatan dan kenyamanan yang terjamin selama dalam perjalanan. Tujuan penelitian adalah untuk mengindentifikasi kinerja mini bus byson dan bus mini hijau jurusan Surabaya - Krian berbasis persepsi penumpang. Metode pendekatan deskriptif kualitatif dengan teknik analisis persentase, komparasi yang bersifat deskriptif naratif. Tahap pengumpulan data dengan kuisioner, observasi dan dokumentasi. Hasil penelitian menurut persepsi penumpang mini bus byson menyatakan bahwa waktu perjalanan mini bus byson cukup baik dengan persentase $61 \%$ dan bus mini hijau masih kurang baik dengan persentase 33\%, tarif mini bus byson Rp5.000 dan bus mini hijau Rp 7.500 , tentang variabel keselamatan dan kenyamanan rata-rata mini bus byson dan bus mini hijau masih kurang dari 50\%. Hasil komparasi kinerja mini bus byson lebih baik pada variabel waktu perjalanan (61\%) dan kelayakan kendaraan (53\%) dengan kategori cukup baik, sedangkan bus mini hijau lebih baik pada variabel pegangan berdiri (67\%) dan kondisi tempat duduk (58\%) dengan persentase cukup baik.
\end{abstract}

Kata kunci: Komparasi,, Performan operasional, Persepsi penumpang

\begin{abstract}
Issues of public transportation in urban areas is the lack of public interest to use the services public transportation, because the community wants the level of services that is adequate which includes the time the journey, tariffs, safety facilities and comfort is guaranteed during the journey. The purpose of this research is to identify the performance of mini bus byson and green mini bus majoring in Surabaya - Krian based on the perception of passengers. Qualitative descriptive approach method with analysis techniques percentage, comparison is descriptive narratives. Data collection stage with the questioner, observation and documentation. Research Results according to the perception of passenger mini bus byson stated that travel time mini bus byson good enough with the percentage of 61 percent and green mini bus is still very less well with the percentage of 33 percent, tarif mini byson bus $\$ 0,37$ and bus mini green $\$ 0,56$, about safety variables and satisfy the average mini bus byson and green mini bus is still less than 50 percent.The results of the comparison of the performance of byson mini buses are better on the travel time variables (48\%) and the feasibility of the vehicle (42\%) with good enough category, while the green bus is better on standing handling variables (46\%) and seating conditions (46\%) with a good percentage.
\end{abstract}

Keywords: Comparison, Operational performance, Perception of passenger 


\section{PENDAHULUAN}

Transportasi merupakan suatu kebutuhkan di perkotaan, karena penduduk membutuhkan media untuk perpindahan tempat (yaitu perpindahan satu tempat ketempat lain) untuk beraktifitas seperti bekerja, sekolah, berdagang, mengunjungi keluarga dan masih banyak lagi. Aktifitas beragam dari penduduk kota maka harus diimbangi dengan tranportasi yang baik karena penumpang memerlukan angkutan umum yang biayanya murah, nyaman dan aman. Terdapat 2 angkutan umum yang memiliki rute Surabaya - Krian yaitu mini bus byson dan bus mini hijau, kedua angkutan umum ini memiliki rute jurusan yang sama yaitu Surabaya - Krian.

Permasalahan angkutan umum di perkotaan, seperti dukungan prasarana dan sarana transportasi, sumber daya manusia, faktor kedisiplinan operator kendaraan, penumpang maupun pengguna jalan, keselamatan dan kenyamanan pengguna jasa transportasi masih belom terjamin (Widayanti, 2014). Permasalahanpermasalahan inilah yang menjadikan moda transportasi saat ini turun peminatnya, sehingga perlu adanya kajian tentang persepsi masyarakat sebagai pengguna jasa transportasi umum. Berdasarkan permasalahan tersebut maka perlu dilakukan penelitian tentang kinerja mini bus byson dan bus mini hijau jurusan Surabaya - Krian berbasis persepsi masyarakat.
Tujuan penelitian ini adalah 1) Untuk mengidentifikasi kondisi eksisting kinerja mini bus byson dan bus mini hijau berbasis persepsi penumpang 2) Untuk mengkomparasi kinerja hasil mini bus byson dan bus mini hijau berbasis persepsi penumpang.

Sesuai dengan Peraturan Menteri Pehubungan Republik Indonesia Nomor 27 Tahun 2015 Tentang Standar Pelayanan Minimal Angkutan Massal Berbasis Jalan dan Surat Keputusan Direktorat Jendral No 687 tahun 2002 tentang Pedoman Teknis Penyelenggaraan Angkutan Penumpang Umum di Wilayah Perkotaan Dalam Trayek Tetap dan Teratur menujukkan bahwa dasar pengguna angkutan menginginkan adanya tingkat pelayanan yang cukup memadai, baik meliputi waktu perjalanan, tarif , keselamatan dan kenyamanan.

\section{METODE PENELITIAN}

Penelitian ini menggunakan metode deskriptif kualitatif dengan cara membandingkan kinerja 2 jenis moda transportasi antara mini bus byson dengan bus mini hijau jurusan Surabaya - Krian. Metode penelitian deskriptif kualitatif berusaha memperlihatkan suatu permasalahan (Kompas.com diakses pada 14/11/2016) terkait waktu perjalanan, tarif, keselamatan dan kenyamanan pengguna jasa angkutan mini bus byson dan bus mini hijau.

Tabel 1

Definisi Operasional Variabel

\begin{tabular}{|c|c|c|}
\hline Informasi dan Kebutuhan Data & Variabel & Data \\
\hline $\begin{array}{l}\text { Mengidentifikasi kondisi eksisting kinerja mini } \\
\text { bus byson dan bus mini hijau berbasis persepsi } \\
\text { penumpang }\end{array}$ & $\begin{array}{ll}\text { - } & \text { Waktu } \\
& \text { perjalanan }\end{array}$ & $\begin{array}{l}\text { - Waktu tempuh per } 1 \\
\text { rit } \\
\text { - Waktu tempuh per } \\
\text { sirkulasi } \\
\text { - Ngetem }\end{array}$ \\
\hline
\end{tabular}


Komparasi Kinerja Mini Bus Byson Dan Bus Mini Hijau Jurusan Surabaya - Krian Berbasis Persepsi Penumpang
- Tarif awal

- Tariff per $(\mathrm{km})$

\begin{tabular}{ll}
- Tarif & - Tarif awal \\
& - Tariff per $(\mathrm{km})$ \\
\hline- Keselamatan & - Kelayakan kendaraan \\
& - P3k dan Palu \\
& - Informasi tanggap \\
& darurat \\
& - Pegangan berdiri \\
& - Pintu masuk dan \\
& keluar penumpang \\
\hline & - Fasilitas kebersihan \\
kenyamanan & - Kondisi tempat duduk \\
& bus \\
& - Kapasitas angkut \\
& - Ventilasi udara \\
& - Lampu Penerangan \\
& - Rel korden di jendela
\end{tabular}

Dalam penelitian ini populasi tidak dapat diketahui dikarenakan penumpang mini bus byson dan bus mini hijau tidak tetap setiap harinya, oleh karena itu digunakan rumus Sampel Linier Time Function (Habibullah, 2013) dengan jumlah 264 responden dari 2 moda armada. Tahap pengumpulan data pada penelitian ini menggunakan kuisioner, observasi lapangan, dokumentasi.

Tipe kuisioner ini menggunakan skala linkert dengan skor $1-5$. Untuk lebih jelasnya dapat dilihat pada Tabel 2 :

Tabel 2

Skala Linkert

\begin{tabular}{|c|c|}
\hline Nilai Skor & Kriteria \\
\hline 1 & Sangat Kurang Baik \\
\hline 2 & Kurang Baik \\
\hline 3 & Cukup Baik \\
\hline 4 & Baik \\
\hline 5 & Sangat Baik \\
\hline
\end{tabular}

pertanyaan-pertanyaan terkait dengan:
1. Waktu perjalanan yang dimana data yang dibutuhkan terkait waktu adalah waktu tempuh per 1 rit, waktu tempuh per sirkulasi dan waktu ngetem.

2. Tarif yang dimana data yang dibutuhkan terkait tariff adalah tariff awal dan tarif per $(\mathrm{Km})$.

3. Keselamatan yang dimana data yang dibutuhkan terkait keselamatan adalah perizinan bus, kelayakan kendaraan, ketersediaan Penanganan Pertama Pada Kecelakaan(P3K), palu, informasi tanggap darurat, pegangan berdiri.

4. Kenyamanan yang dimana data yang dibutuhkan terkait kenyamanan adalah fasilitas kebersihan, kondisi tempat duduk bus, kapsitas angkut, jumlah penumpang, lampu penerangan, kondisi atap halte dan kebersihan halte.

Lokasi penelitian pada penelitian ini berada di jalur trayek Mini Bus Byson dan Bus Mini Hijau di mulai dari Terminal Joyoboyo hingga menuju ke Terminal Krian, 
untuk lebih jelasnya dapat dilihat pada Gambar 1.

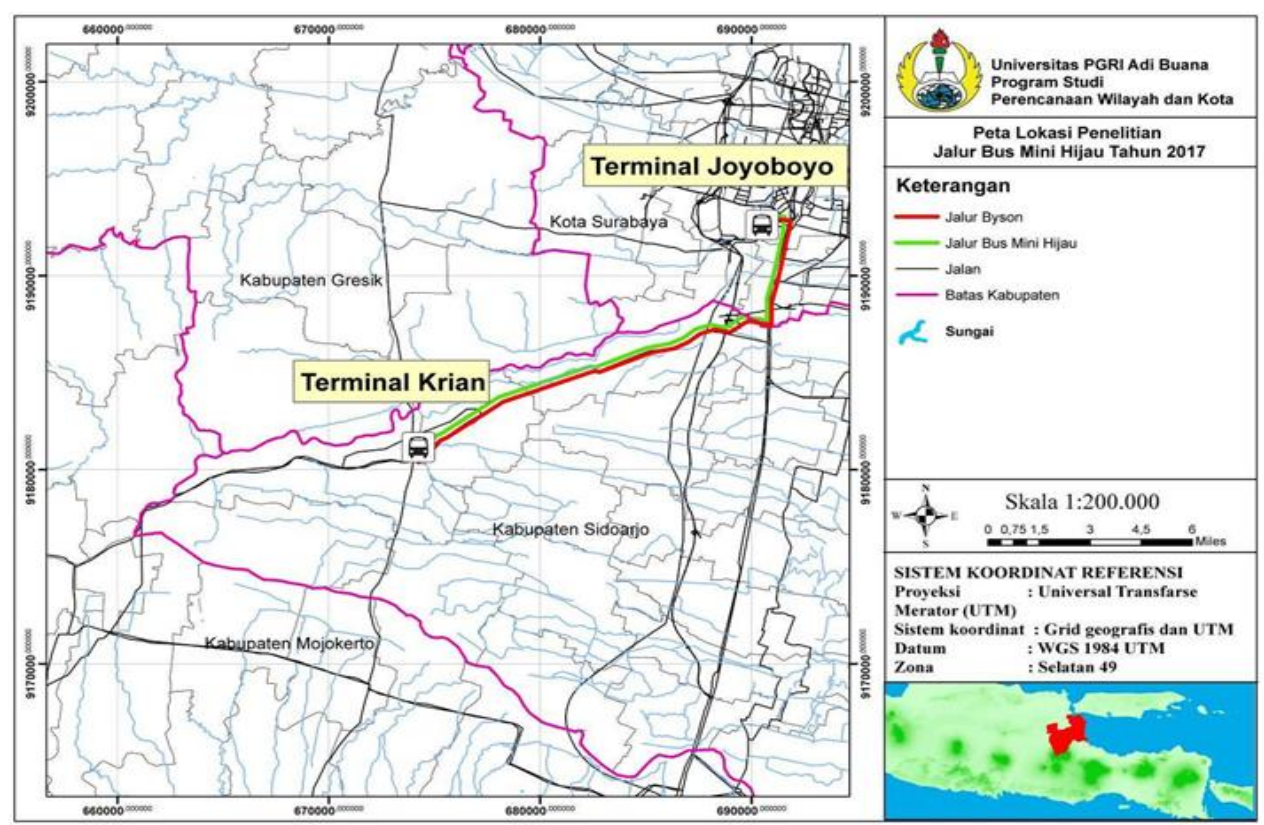

Gambar 1. Peta Wilayah Studi

3. HASIL DAN PEMBAHASAN

1) Analisis Kondisi Eksisting Kinerja Mini Bus Byson dan Bus Mini Hijau Jurusan Surabaya - Krian Berbasis Persepsi Penumpang.

Dalam menentukan kondisi eksisting kinerja mini bus byson dan bus mini hijau jurusan Subaraya - Krian berbasis persepsi penumpang. Peneliti melakukan penyebaran kuisioner tertutup dan observasi secara dinamis serta wawancara mendalam.

\section{a. Waktu Perjalanan}

Analisis penelitian ini lebih memfokuskan pasa aspek waktu per 1 rit, waktu per sirkulasi dan waktu ngetem. Panjang rute mini bus byson adalah $26,7 \mathrm{~km}$ dari arah terminal Joyoboyo - Terminal Krian diperoleh waktu perjalanan per 1 rit adalah 28 - 33 menit, waktu henti atau ngetem mini bus byson per 1 rit adalah 5 menit. Perjalanan mini bus byson per 1 sirkulasi (dari terminal Joyoboyo ke terminal Krian kembali lagi ke terminal Joyoboyo) diperoleh waktu rata-rata perjalanan adalah 72 - 76 menit. Bus mini hijau memiliki panjang rute $26,9 \mathrm{~km}$ dari arah terminal Joyoboyo menuju terminal Krian memperoleh waktu rata-rata per 1 rit adalah 44 - 48 menit, dengan waktu ngetem 2 kali 10 menit. Sedangkan perjalanan dari arah terminal Krian menuju terminal Joyoboyo 40 menit. Perjalanan 1 sirkulasi bus mini hijau (dari terminal Joyoboyo ke terminal Krian lalu kembali menuju terminal Joyoboyo) ditempuh dalam kurun waktu rata-rata 108 116 menit. Untuk lebih jelasnya dapat dilihat pada Tabel 3 .

Tabel 3

Waktu Perjalanan Tahun 2017

\begin{tabular}{cccc}
\hline Jenis & $\begin{array}{c}\text { Waktu } \\
\text { Tempuh }\end{array}$ & $\begin{array}{c}\text { Waktu } \\
\text { Perjalanan } \\
\text { (Menit) }\end{array}$ & $\begin{array}{c}\text { Waktu } \\
\text { Ngetem } \\
\text { (Menit) }\end{array}$ \\
\hline $\begin{array}{c}\text { Mini Bus } \\
\text { Byson }\end{array}$ & Per 1 rit & $28-33$ & 5 \\
\cline { 2 - 4 } & $\begin{array}{c}\text { Per } \\
\text { sirkulasi }\end{array}$ & $72-76$ & 10 \\
\hline Bus Mini & Per 1 rit & $44-48$ & $10(2 \mathrm{x})$ \\
\hline
\end{tabular}


Volume 71, Nomor 1, 1 Juni 2019

\begin{tabular}{cccc}
\hline Jenis & $\begin{array}{c}\text { Waktu } \\
\text { Tempuh }\end{array}$ & $\begin{array}{c}\text { Waktu } \\
\text { Perjalanan } \\
\text { (Menit) }\end{array}$ & $\begin{array}{c}\text { Waktu } \\
\text { Ngetem } \\
\text { (Menit) }\end{array}$ \\
\hline Hijau & $\begin{array}{c}\text { Per } \\
\text { sirkulasi }\end{array}$ & $108-116$ & 40 \\
\hline
\end{tabular}

Sumber : Hasil Survey 2017

Berdasarkan Tabel 3 hasil pengamatan di lapangan, maka dibutuhkan persepsi penumpang tentang kebutuhan menggunakan kedua moda angkutan ini. Untuk lebih jelasnya dapat dilihat pada Tabel 4.

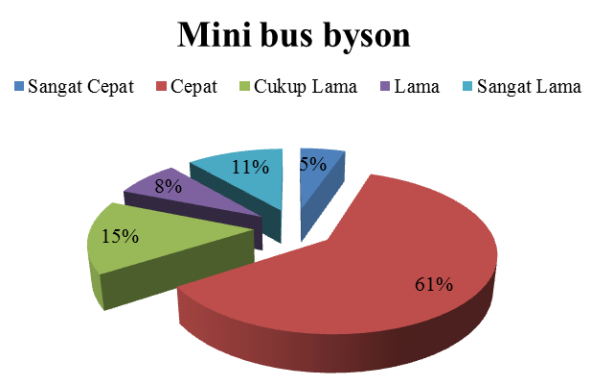

\section{Tabel 4}

Persepsi Kebutuhan Kinerja Mini bus byson dan Bus mini hijau Tahun 2017

\begin{tabular}{|c|c|c|c|c|c|}
\hline \multirow[t]{3}{*}{ Jenis } & \multicolumn{5}{|c|}{$\begin{array}{c}\text { Waktu Tempuh Perjalanan dengan Kebutuhan } \\
\text { Penumpang }\end{array}$} \\
\hline & $\begin{array}{l}\text { Sangat } \\
\text { Cepat }\end{array}$ & Cepat & $\begin{array}{l}\text { Cukup } \\
\text { Lama }\end{array}$ & Lama & $\begin{array}{l}\text { Sangat } \\
\text { Lama }\end{array}$ \\
\hline & 5 & 4 & 3 & 2 & 1 \\
\hline $\begin{array}{c}\text { Mini } \\
\text { bus } \\
\text { byson }\end{array}$ & 7 & 80 & 20 & 10 & 15 \\
\hline $\begin{array}{l}\text { Bus } \\
\text { mini } \\
\text { hijau }\end{array}$ & 5 & 18 & 27 & 39 & 43 \\
\hline
\end{tabular}

Sumber : Hasil Survey 2017

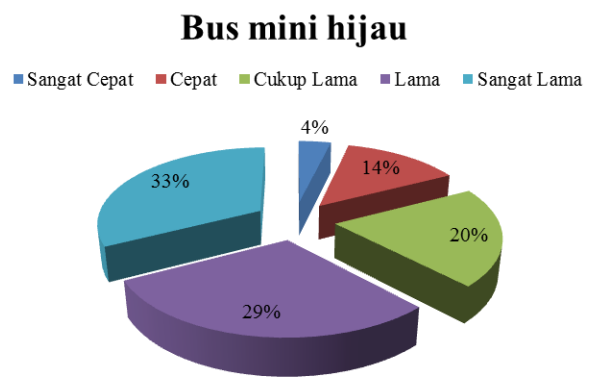

Gambar 2. Persepsi Kebutuhan Kinerja Mini Bus Byson dan Bus Mini Hijau

Berdasarkan Tabel 3 dan Gambar 2 waktu perjalanan angkutan dengan kebutuhan penumpang. Mini bus byson menunjukkan bahwa menurut persepsi penumpang terhadap waktu tempuh dengan kriteria cepat memiliki persentase $61 \%$ mini bus byson termasuk dalam kriteria cukup baik. Penumpang merasa cukup baik dengan menggunakan angkutan mini bus byson ini. Menurut penumpang bus mini hijau sendiri memiliki persentase $33 \%$ yang menyatakan sangat lama dan angkutan ini termasuk kategori sangat kurang baik. Lama perjalanan dan waktu ngetem menjadi permasalahan pada moda angkutan ini, dikarenakan memiliki 2 kali waktu ngetem dan memakan waktu 20 menit.

\section{b. Tarif}

Berdasarkan survey dilapangan tarif untuk mini bus byson dan bus mini hijau jurusan Terminal Joyoboyo - Terminal Krian dibedakan menjadi 2 yaitu, tarif untuk pelajar dan tarif dewasa/pekerja. Rata - rata tarif untuk siswa yang masih berseragam akan dikenakan tarif kurang dari Rp. 5.000, sedangkan untuk dewasa tarif yang dikenakan antara Rp. 5.000 - Rp. 7.500. Tarif yang ditetapkan oleh Peraturan Gubernur Jawa Timur No 27 Tahun 2016 Tentang tarif dasar serta tarif jarak batas atas dan batas bawah angkutan penumpang antar kota dalam provinsi kelas ekonomi menggunakan mobil dan bus umum. Terkait tarif penumpang antar kota dalam provinsi Rp. 166 per $\mathrm{Km}$ tidak terpaut jauh dengan kondisi dilapangan terutama untuk pelajar, untuk pekerja/dewasa dikenakan tarif ratarata $\mathrm{Rp} 7.500-\mathrm{Rp} 4432=\mathrm{Rp} 3068$ terjadi kenaikan $87,5 \%$ dilapangan. Untuk lebih jelasnya ada pada Tabel 5 dan Gambar 3 . 
Volume 71, Nomor 1, 1 Juni 2019

Tabel 5

Jumlah Penumpang Angkutan Mini Bus Byson dan Bus Mini Hijau Tahun 2017

\begin{tabular}{lc}
\hline & Tarif Mini Bus Byson \\
\hline Pelajar/ Mahasiswa & 28 \\
\hline Desawa/ Pekerja & 104 \\
\hline Jumlah & 132 \\
\hline & Tarif Bus Mini Hijau \\
\hline Pelajar/ Mahasiswa & 43 \\
\hline Desawa/ Pekerja & 89 \\
\hline \multicolumn{1}{c}{ Jumlah } & 132 \\
\hline
\end{tabular}

Sumber : Hasil Survey 2017

\section{Bus Mini Byson}

"Tarif Mini Bus Byson $=$ Pelajar/Mahasiswa $\square$ Desawa/ Pekerja

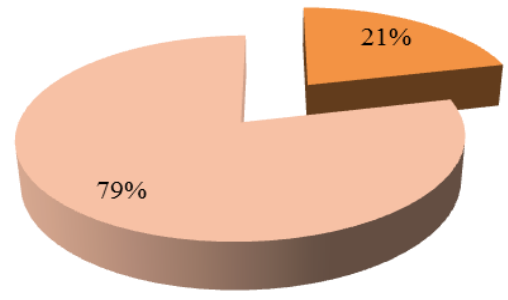

Penumpang Bus Mini Hijau Tahun 2017

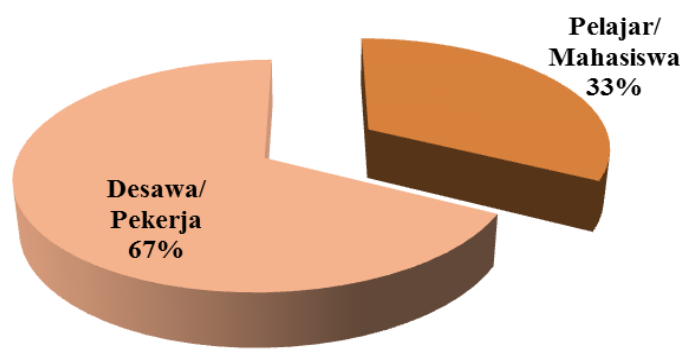

Sumber : Hasil Survey 2017

Gambar 3. Persentase Penumpang

Berdasarkan Tabel 3 dan Gambar 3 dapat diketahui dari 132 responden penumpang Mini Bus Byson sebanyak 104 responden adalah pekerja/karyawan dengan persentase $79 \%$. Bus mini hijau tidak jauh berbeda yaitu 89 responden merupakan pekerja/karyawan dengan persentase $67 \%$. Maka rata-rata pengguna angkutan umum ini kebanyakan berstatus pekerja/karyawan.

\section{c. Keselamatan}

Analisa tentang variabel keselamatan terbagi menjadi kelayakan kendaraan, palu pemecah kaca, ketersediaan kotak p3k, informasi tanggap darurat pegangan untuk berdiri, pintu masuk dan keluar.

\section{Kelayakan Kondisi Kendaraan}

Kondisi kendaraan angkutan umum merupakan hal yang memiliki daya jual tersendiri bagi pengguna moda angkutan umum. Berdasarkan skala likert untuk mengukur sikap, pendapat dan persepsi seseorang atau sekelompok tentang kejadian atau gejala social. ntuk lebih jelasnya dapat dilihat pada

Tabel

6.

Tabel 6

Persepsi Penumpang Tentang Kelayakan Kondisi Kendaraan Tahun 2017

\section{Jenis}

\begin{tabular}{lllll}
\hline Sangat baik & Baik & Cukup baik & Kurang & Sangat tidak
\end{tabular}




\begin{tabular}{cccccc}
\hline & & & & Baik & baik \\
\cline { 2 - 6 } & 5 & 4 & 3 & 2 & 1 \\
\hline Mini bus byson & 23 & 70 & 22 & 12 & 5 \\
\hline Bus mini hijau & 8 & 64 & 30 & 18 & 12 \\
\hline Sum
\end{tabular}

Sumber: Hasil Survey 2017
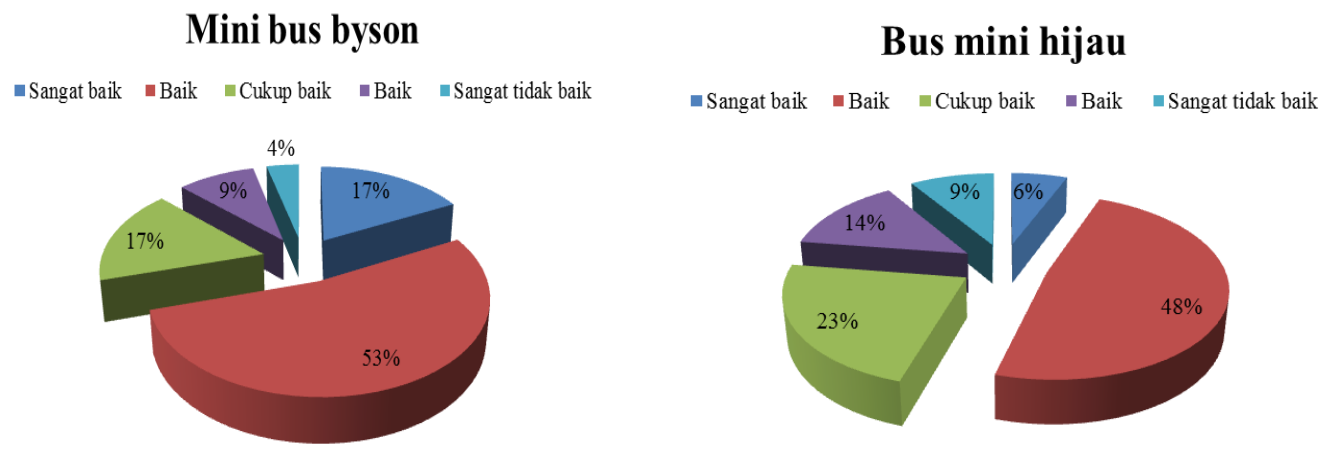

Gambar 4. Diagram Kelayakan Kendaraan

Berdasarkan Tabel 4 dan Gambar 4 Hasil perhitungan menggunakan kuisioner dengan 264 responden dalam 2 trayek yaitu mini bus byson dan bus mini hijau. Didapati persepsi penumpang tentang kondisi yang menyatakan baik. Penumpang merasa cukup baik dalam menggunakan angkutan bus mini hijau ini.

\section{Palu Pemecah Kaca, Ketersediaan Kotak P3K, Informasi Tanggap Darurat}

Berdasarkan hasil survey kuisioner kepada penumpang dan observasi kepada pengemudi angkutan umum di lapangan. Fasilitas kesehatan yakni berupa kotak P3K (Penanganan Pertama Pada Kecelakaan), palu kendaraan mini bus byson dengan persentase 53\% yang menyatakan baik. Penumpang merasa cukup baik dengan menggunakan angkutan mini bus byson ini. Bus mini hijau dengan persentase 39\% pemecah kaca dan informasi tanggap darurat di angkutan mini bus byson dan bus mini hijau $100 \%$ belum tersedia. Jika dalam keadaan darurat dapat merugikan penumpang dalam angkutan mini bus byson dan bus mini hijau. Untuk lebih jelasnya dapat dilihat contoh pada Gambar 5. 

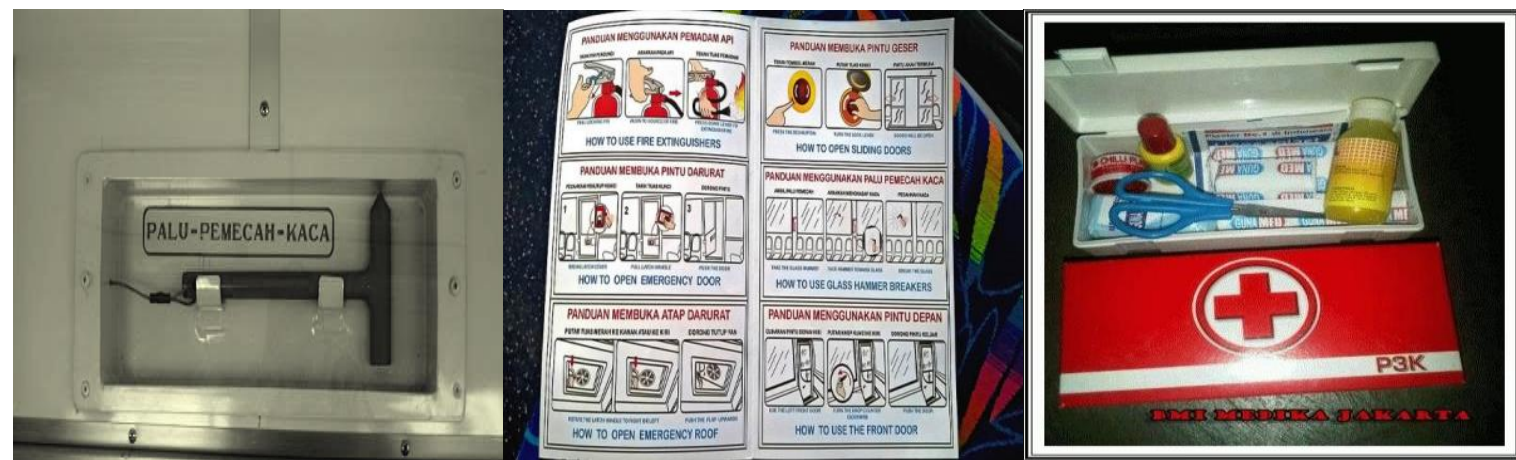

Gambar 5. Palu Pemecah Kaca, Informasi Tanggap Darurat, Kotak P3K

\section{Pegangan Penumpang Untuk berdiri}

Berdasarkan survey dilapangan tidak semua moda angkutan menyediakan pegangan di dalam kabin kendaraan, maka diambilah persepsi penumpang untuk melihat ketersediaan pegangan berdiri dari sisi penumpang.

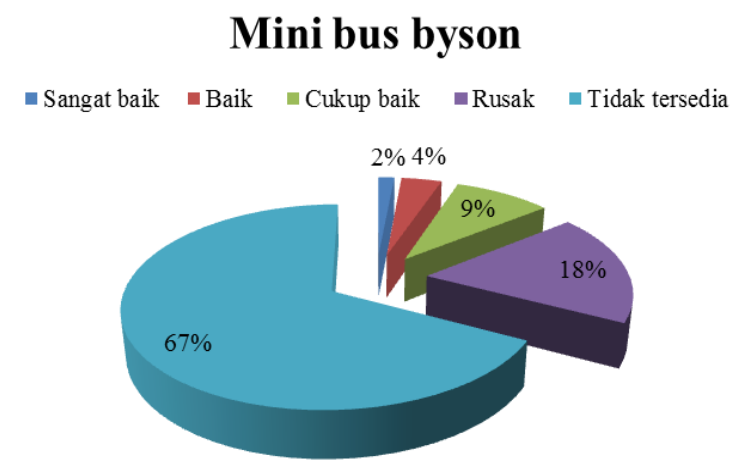

Tabel 7

Persepsi Penumpang Tentang Kondisi Ketersediaan Pegangan Penumpang Tahun 2017

\begin{tabular}{cccccc}
\hline Jenis & \multicolumn{5}{c}{ Kategori Kondisi Pegangan Penumpang } \\
\cline { 2 - 6 } & $\begin{array}{c}\text { Sangat } \\
\text { baik }\end{array}$ & Baik & $\begin{array}{c}\text { Cukup } \\
\text { baik }\end{array}$ & Rusak & $\begin{array}{c}\text { Tidak } \\
\text { tersedia }\end{array}$ \\
\cline { 2 - 6 } & 5 & 4 & 3 & 2 & 1 \\
\hline $\begin{array}{c}\text { Mini } \\
\text { bus } \\
\text { byson }\end{array}$ & 2 & 5 & 12 & 24 & 89 \\
\hline $\begin{array}{c}\text { Bus } \\
\text { mini } \\
\text { hijau }\end{array}$ & 19 & 76 & 23 & 9 & 5 \\
\hline
\end{tabular}

Sumber : Hasil Survey 2017

\section{Bus mini hijau}

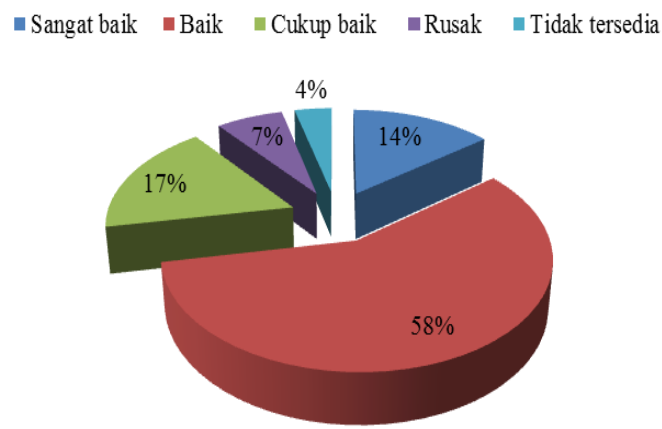

Gambar 6. Persentase Kondisi Ketersediaan Pegangan Penumpang

Berdasarkan Tabel 7 merupakan hasil pengamatan di lapangan, fasilitas pegangan penumpang untuk berdiri rata -rata sudah tersedia di angkutan bus mini hijau. Memiliki persentase $58 \%$ penumpang menyatakan tersedia pegangan untuk berdiri dan termasuk 
kategori cukup baik, sehingga keselamatan penumpang ketika tidak mendapatkan tempat duduk dapat berdiri dengan aman. Mini bus byson tidak menyediakan fasilitas pegangan untuk berdiri dengan persentase 67\% penumpang menyatakan tidak tersedia pegangan. Namun moda angkutan ini berbentuk elf dan tidak dapat berdiri didalam angkutan. Mini bus byson menyediakan pegangan untuk naik-turun yang terletak didalam mobil bus dipinggir langit-langit.

\section{Pintu Masuk dan Keluar Penumpang}

Berdasarkan gambar dapat diliat bahwa mini bus byson hanya memiliki 3 buah pintu masuk dan keluar, posisi pintu terdapat pada bagian depan sebelah kanan dan kiri terdapat 2 pintu yaitu pintu masuk dan keluar penumpang dan sopir, samping kendaraan bagian tengah terdapat 1 buah pintu. Bus mini hijau pun sama memiliki 3 buah pintu masuk dan keluar, posisi pintu terdapat pada bagian depan sebelah kanan dan kiri tengah terdapat 2 pintu yaitu pintu masuk dan keluar penumpang dan sopir, pada samping kendaraan terletak sedikit belakang terdapat 1 buah pintu. Untuk lebih jelasnya dapat dilihat pada gambar 7 berikut:

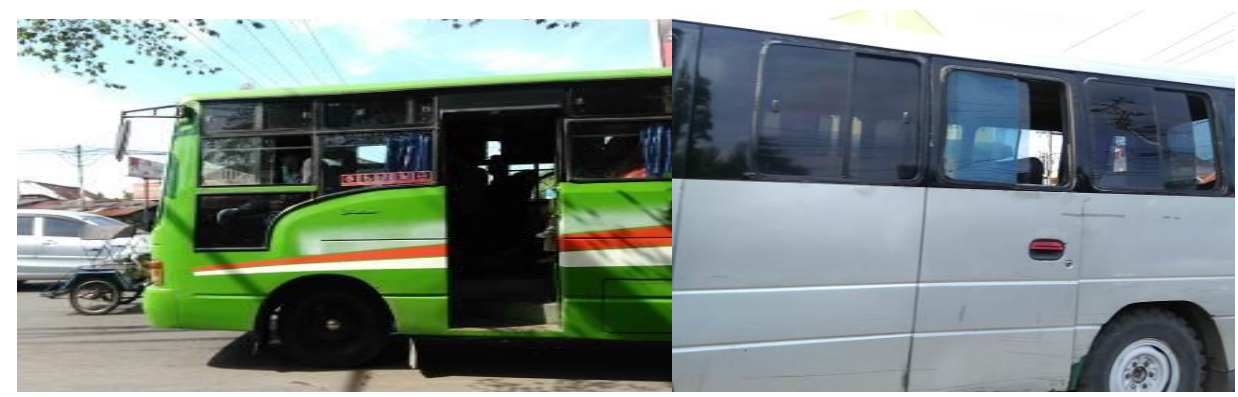

Gambar 7. Pintu Masuk dan Keluar Mini Bus Byson dan Bus Mini Hijau Tahun 2017 Sumber : Hasil Survey 2017

\section{d. Kenyamanan}

Analisa tentang variabel kenyamanan terbagi menjadi Fasilitas kebersihan, kondisi tempat duduk, kapasitas angkut, ventilasi udara, lampu penerangan, rel korden. Untuk lebih jelasnya dapat dilihat pada Tabel 8 .

\section{Fasilitas Kebersihan}

Berdasarkan hasil survey dilapangan didapatin fasilitas kebersihan di kedua moda angkutan belum tersedia.

Tabel 8

Persepsi Penumpang Tentang Kondisi Ketersediaan Tempat Sampah di Angkutan Tahun 2017

\begin{tabular}{cccccc}
\hline \multirow{2}{*}{ Jenis } & \multicolumn{5}{c}{ Kategori Kondisi Kendaraan } \\
\cline { 2 - 6 } & Sangat baik & Baik & Cukup baik & Baik & Tidak tersedia \\
\cline { 2 - 6 } & 5 & 4 & 3 & 2 & 1 \\
\hline Mini bus byson & - & - & - & - & 132 \\
\hline Bus mini hijau & - & - & - & - & 132 \\
\hline Sumber: Hasil Survey 2017 & & & & \\
Tabel 8 hasil & analisa & mengenai & & mini byson dan bus mini hijau. Mengenai \\
ketersediaan fasilitas kebersihan berupa
\end{tabular}


tempat sampah disetiap mobil bus wajib disediakan minimal 1 buah, sesuai dengan peraturan yang telah ditetapkan. Hasil pengamatan menyatakan $100 \%$ kedua moda angkutan tidak menyediakan tempat sampah di setiap mobil bus. Perhitungan dengan skala likert persepsi penumpang tenang kondisi ketersediaan tempat sampah pada kedua moda tersebut dihasilkan keduanya memiliki persentase $20 \%$ atau sangat kurang baik.

\section{Kondisi Tempat Duduk Bus}

Tempat duduk angkutan umum merupakan faktor penting untuk menunjang kenyamanan pengguna angkutan umum. Jika tempat duduk tidak terawat, rusak maka akan mengurangi minat pengguna angkutan umum untuk menggunakan jasa transportasinya. Untuk lebih jelasnya dapat dilihat pada Tabel 9.

Tabel 9

Persepsi Penumpang Tentang Kondisi Tempat duduk Tahun 2017

\begin{tabular}{cccccc}
\hline Jenis & \multicolumn{5}{c}{ Kondisi Tempat Duduk } \\
\cline { 2 - 6 } & $\begin{array}{c}\text { Sangat } \\
\text { terawat }\end{array}$ & Terawat & $\begin{array}{c}\text { Cukup } \\
\text { terawat }\end{array}$ & $\begin{array}{c}\text { Tidak } \\
\text { terawat }\end{array}$ & $\begin{array}{c}\text { Sangat tidak } \\
\text { terawat }\end{array}$ \\
\cline { 2 - 6 } & 5 & 4 & 3 & 2 & 1 \\
\hline $\begin{array}{c}\text { Mini Bus } \\
\text { Byson }\end{array}$ & 3 & 17 & 22 & 47 & 43 \\
\hline Bus & 11 & 76 & 34 & 11 & - \\
Mini & & & & & \\
Hijau & & & & & \\
\hline
\end{tabular}

Sumber : Hasil Survey 2017
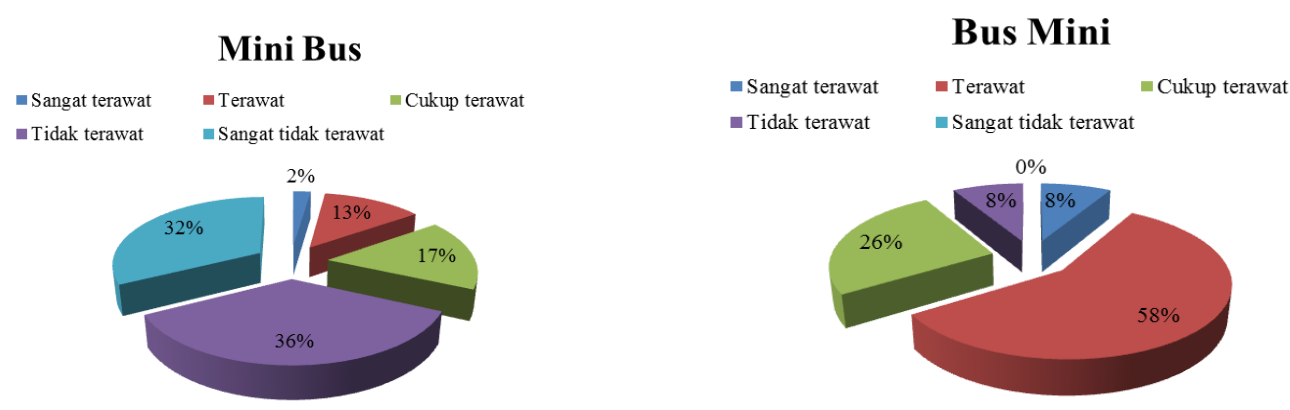

Gambar 8. Diagram Kondisi Tempat Duduk Tahun 2017

Tabel 9 hasil analisa mengenai kondisi tempat duduk angkutan umum. persepsi penumpang tentang kondisi tempat duduk mini bus byson dengan persentase $36 \%$ menyatakan tidak terawat. Bus mini hijau dengan persentase $58 \%$ menyatakan terawat. Perawatan yang rutin demi memberi kenyamanan pengguna jasa bus mini hijau tetap dijaga dengan selalu membersihkan dan mengganti sarung tempat duduk.

\section{Kapasitas Angkut}

Berdasarkan survey dilapangan didapati Kapasitas penumpang atau pengguna jasa angkutan harus sesuai dengan jumlah tempat duduk yang disediakan. Mini bus byson memiliki jumlah tempat duduk untuk 9 orang dan bus mini hijau memiliki jumlah tempat 
Volume 71, Nomor 1, 1 Juni 2019

duduk sebanyak 45 orang. Untuk lebih jelasnya dapat dilihat pada Tabel 10.

\section{Tabel 10}

Kapasitas Angkut Tahun 2017

\begin{tabular}{ccccc}
\hline Jenis & \multicolumn{3}{c}{ Kapasitas } & Total diangkut \\
\cline { 2 - 5 } & Tersedia & Duduk & Berdiri & \\
\hline MBB & 9 & 13 & - & 13 \\
\hline BMH & 30 & 30 & 15 & 45
\end{tabular}

Sumber : Hasil Survey 2017

Tabel 10 menggambarkan bahwa mini bus byson hanya dapat memuat sebanyak 9 penumpang, sedangkan bus mini hijau dapat memuat sebanyak 30 penumpang. Sering kali Mini bus byson dan Bus mini hijau dapat memuat melebihi kapasitas tempat duduk, hasil pengamatan di lapangan mengenai Kapasitan penumpang yang dapat di angkut dalam angkutan umum mini bus byson berjumlah 4 baris bangku panjang yang sejajar dan 1 bangku cadangan yang diletakkan ditengah. Mini bus byson total dapat memuat 13 penumpang. Bus mini hijau memiliki jumlah bangku 30, dan disediakan pegangan untuk berdiri bagi penumpang yang tidak mendapatkan tempat duduk. Bus mini hijau dapat memuat melebihi kapasitas yaitu 45 penumpang bahkan lebih.

\section{Ventilasi Udara}

Setiap ruang pada moda angkutan umum memerlukan sirkulasi udara agar pengguna jasa dapat merasa nyaman dengan keadaan didalam angkutan. Untuk lebih jelasnya dapat dilihat pada Tabel 11 dan Gambar 9.

Tabel 11

Persepsi Penumpang Tentang Fasilitas Ventilasi Udara Tahun 2017

\begin{tabular}{cccccc}
\hline Jenis & \multicolumn{6}{c}{ Kondisi Ventilasi Udara } \\
\cline { 2 - 6 } & Sangat baik & Baik & Cukup baik & Rusak & $\begin{array}{c}\text { Sangat tidak } \\
\text { baik }\end{array}$ \\
\cline { 2 - 7 } & 5 & 4 & 3 & 2 & 1 \\
\hline MBB & 17 & 35 & 49 & 26 & 5 \\
\hline BMH & 23 & 67 & 25 & 14 & 3 \\
\hline
\end{tabular}

Sumber : Hasil survey 2017 


\section{Mini Bus Byson}

$\backsim$ Sangat terawat $\backsim$ Terawat $\backsim$ Cukup terawat $\backsim$ Rusak $\backsim$ Sangat tidak terawat

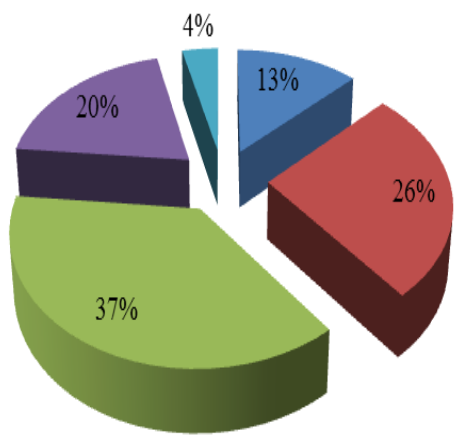

Bus Mini Hijau

$\backsim$ Sangat terawat $\square$ Terawat $\backsim$ Cukup terawat $\backsim$ Rusak $\backsim$ Sangat tidak terawat

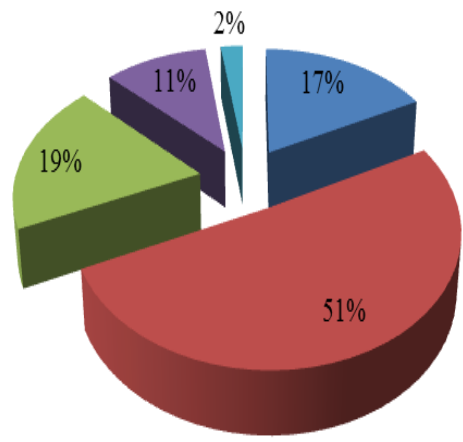

Gambar 9. Diagram Fasilitas Ventilasi Udara Tahun 2017

Tabel 11 hasil analisa perhitungan mini bus byson didapati $37 \%$ menyatakan ventilasi udara cukup baik walaupun jendela kaca tidak semua dapat digunakan dengan baik. Bus mini hijau diperoleh $51 \%$ menyatakan ventilasi baik. Sehingga penumpang merasa cukup baik dengan menggunakan angkutan bus mini hijau. Secara kebutuhan penumpang ventilasi udara disetiap moda angkutan tersebut seharusnya memadai dengan 1 baris bangku mendapat 1 ventilasi udara. Mengacu pada standar kenyamanan angkutan umum harus menyediakan Air Conditioner (AC) dan fasilitas pengatur suhu dalam kabin dengan suhu maksimal $25-27 * \mathrm{C}$. fasilitas ini dapat menarik pengguna jasa angkutan agar tertarik menggunakan jasa angkutan ini.

\section{Lampu Penerangan}

Berdasarkan fungsi lampu penerangan merupakan sumber cahaya didalam kabin kendaraan untuk memberikan kenyamanan bagi pengguna jasa. Ketersediaan lampu penerangan digunakan ketika keadaan mulai gelap atau pada waktu sore hari. Untuk lebih jelasnya dapat dilihat pada Tabel 12 .

Tabel 12

Persepsi Penumpang Tentang Fasilitas Lampu Penerangan Tahun 2017

\begin{tabular}{cccccc}
\hline Jenis & \multicolumn{5}{c}{ Kondisi Lampu Penerangan } \\
\cline { 2 - 6 } & $\begin{array}{c}\text { Sangat } \\
\text { Baik }\end{array}$ & Baik & $\begin{array}{c}\text { Cukup } \\
\text { Baik }\end{array}$ & Rusak & $\begin{array}{c}\text { Sangat } \\
\text { Tidak } \\
\text { Tersedia }\end{array}$ \\
\cline { 2 - 6 } & 5 & 4 & 3 & 2 & 1 \\
\hline Mini bus byson & 2 & 13 & 17 & 34 & 66 \\
\hline Bus mini hijau & 5 & 21 & 5 & 22 & 79 \\
\hline
\end{tabular}

Sumber : Hasil Survey 2017 


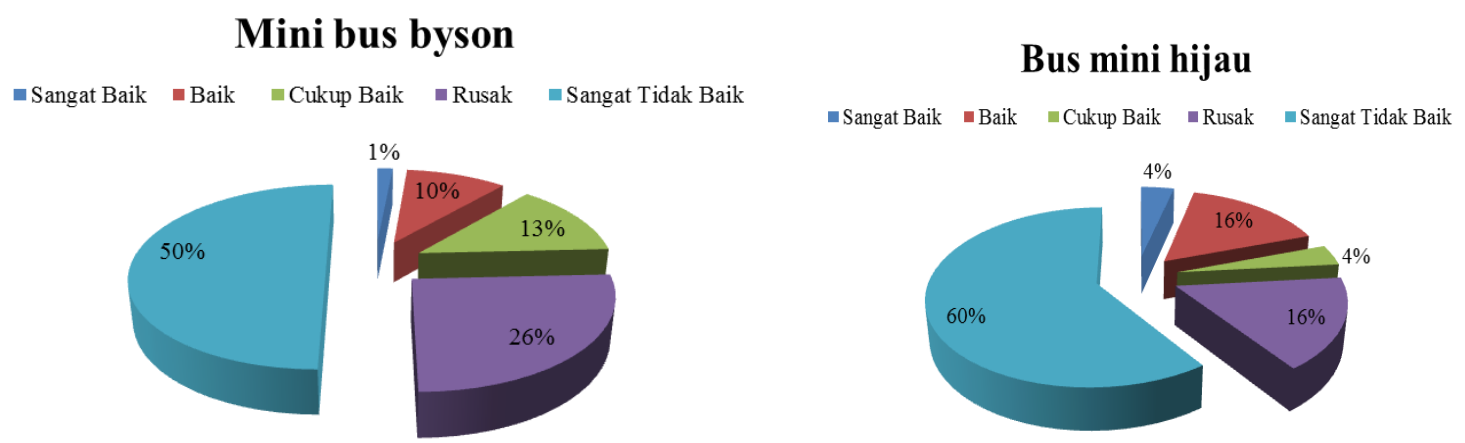

Gambar 10. Diagram Fasilitas Lampu Penerangan Tahun 2017

Tabel 12 dapat diketahui persepsi penumpang mini bus byson menyatakan tidak tersedianya fasilitas lampu penerangan sebesar 50\% menyatakan tidak tersedia. Menurut persepsi penumpang untuk lampu penerangan didalam mini bus byson tidak tersedia bahkan jika adapun tidak berfungsi dengan baik. Bus mini hijau dengan memiliki persentase $60 \%$ menyatakan tidak tersedia, untuk bus mini hijau menurut persepsi penumpang memang tidak sedikit yang menyediakan lampu penerangan didalam kabin angkutan untuk berjaga-jaga saja. Hasil

Tabel 13

Persepsi Penumpang Tentang Fasilitas Rel Gorden Tahun 2017

\begin{tabular}{cccccc}
\hline Jenis & \multicolumn{5}{c}{ Kondisi Rel Korden } \\
\cline { 2 - 6 } & $\begin{array}{c}\text { Sangat } \\
\text { Baik }\end{array}$ & Baik & $\begin{array}{c}\text { Cukup } \\
\text { Baik }\end{array}$ & Rusak & $\begin{array}{c}\text { Sangat Tidak } \\
\text { Baik }\end{array}$ \\
\cline { 2 - 6 } & 5 & 4 & 3 & 2 & 1 \\
\hline Mini bus byson & 7 & 18 & 51 & 16 & 40 \\
\hline Bus mini hijau & 10 & 20 & 33 & 7 & 62 \\
\hline
\end{tabular}

Sumber : Hasil Survey 2017

Mini bus byson

- Sangat Baik - Baik =Cukup Baik - Rusak = Sangat Tidak Baik

$\backsim$ Sangat Baik $\quad$ Baik $\quad$ Cukup Baik $\quad$ Rusak $\quad$ Sangat Tidak Baik
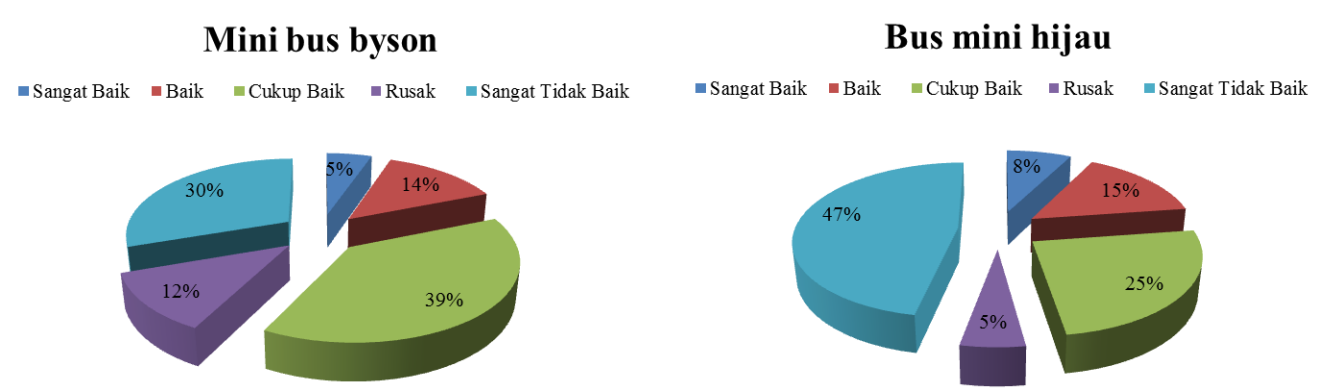

Gambar 11. Diagram Fasilitas Rel Gorden Tahun 2017 pengamatan lapangan bus hijau sendiri hanya menyediakan penerangan dengan lampu berukuran 5 - 10 Watt.

\section{Rel Korden}

Ketersediaan gorden merupakan fasilitas kenyamanan angkutan yang diperlukan pengguna jasa agar terhindar dari panas teriknya matahari di kala siang hari. Posisi rel gorden terpasang tidak menggangu evakuasi apabila terjadi keadaan darurat(pada saat kaca harus dipecahkan). Untuk lebih jelasnya dapat dilihat pada Tabel 13 dan Gambar 11. 
Tabel 13 perhitungan ketersediaan rel gorden dapat diketahui persepsi penumpang mini bus byson menyatakan cukup baik dengan persentase 39\%. Bus mini hijau penumpang menyatakan sangat tidak baik untuk fasilitas rel gorden dengan persentase 47\%. Persepsi penumpang mini bus byson menyatakan hanya beberapa angkutan mini bus byson yang menyediakan rel korden didalam angkutannya, rata - rata yang menyediakan rel korden. Para pemilik perorangan selalu merawat dengan rutin dan memberi kenyamanan total untuk menarik pengguna jasa angkutan. Ketersediaan rel gorden wajib terpenuhi atau tersedia sesuai Peraturan yang telah ditetapkan, dikarenakan salah satu faktor kenyamanan untuk pengguna jasa angkutan.

2) Hasil Analisis Komparasi Mini Bus Byson dan Bus Mini Hijau Tahun 2017

Untuk variabel waktu perjalanan Berdasarkan hasil analisis, waktu rit mini bus byson lebih cepat dibandingkan dengan bus mini hijau selisih 15-16 menit. Waktu sirkulasi mini bus byson lebih cepat dibandingkan dengan bus mini hijau dengan selisih 36-40 menit. Sedangkan waktu ngetem mini bus byson lebih cepat selisih 5 menit dibandingkan bus mini hijau yang waktu ngetem 10 menit. Sedangkan mengenai tarif pada kedua moda angkutan untuk pelajar memiliki kesamaan. Pada tarif pekerja mini bus byson lebih murah sebesar Rp. 2.500 dari bus mini hijau.

Fasilitas keselamatan seperti kondisi kendaraan baik mini bus byson dan bus mini hijau masih layak jalan akan tetapi mini bus byson lebik banyak menyediakan armada dibandingkan bus mini hijau. Sedangkan fasilitas kesehatan antara kedua angkutan umum tersebut adanya kesamaan tidak tersedianya kotak P3K, palu pemecah kaca, informasi tanggap darurat. Secara keamanan bus mini hijau sudah dilengkapi pegangan tangan untuk berdiri sedangkan mini bus byson tidak tersedia. Untuk fasilitas pintu masuk dan keluar penumpang mini bus byson memiliki pintu yang tertutup ketika kendaraan bergerak sedangkan bus mini hijau tetap terbuka ketika bergerak.

Fasilitas kenyamanan Berdasarkan hasil survey, ketersediaan fasilitas kebersihan kedua moda angkutan tidak menyediakan tempat sampah. Kondisi tempat duduk bus mini hijau juga terlihat lebih terawat terdapat sarung pada tempat duduknya dibandingkan dengan mini bus byson masih terdapat tempat duduk yang rusak dan tidak layak, sedangkan jumlah penumpang yang di angkut bus mini hijau lebih banyak selisih 32 penumpang dari mini bus byson, akan tetapi kekurangan dari bus mini hijau adalah sering kali memaksakan penumpang yang artinya kapasitas muatan melebihi kapasitas. Mengenai fasilitas ventilasi udara bus mini hijau lebih baik $51 \%$ dibandingkan mini bus byson sebesar $37 \%$ menurut persepsi penumpang. Fasilitas lampu penerangan mini bus byson tidak terpaut jauh dengan bus mini hijau selisih $10 \%$ menyatakan tidak menyediakan. Rel korden mini bus byson memiliki persentase cukup baik sebesar 39\% menyatakan cukup tersedia dan lebih baik dibandingkan bus mini hijau sebesar $47 \%$ yang menyatakan tidak menyediakan.

\section{KESIMPULAN}

Berdasarkan hasil uraian diatas, maka penelitian ini dapat disimpulkan sebagai berikut :

1. Berdasarkan hasil interpretasi kriteria persentase persepsi penumpang tahun 2017. Mini bus byson memiliki 4 kriteria yaitu cukup baik, Kriteria cukup baik mencakup beberapa variabel yaitu waktu perjalanan 
dengan presentase $61 \%$, keselamatan terkait kelayakan kendaraan dengan persentase $67 \%$, ventilasi udara dengsn persentasi $37 \%$, rel korden dengan persentase $39 \%$. Bus mini hijau memiliki 3 kriteria hasil persepsi penumpang yaitu cukup baik. Kriteria cukup baik mencakup beberapa variabel yaitu pegangan penumpang untuk beridiri dengan persentase $58 \%$, kondisi tempat duduk dengan persentase $58 \%$, kondisi ventilasi udara dengan persentase $51 \%$.

2. Komparasi antara mini bus byson dan bus mini hijau menyatakan bahwa waktu rit mini bus byson lebih cepat dibandingkan dengan bus mini hijau selisih 15-16 menit. Waktu sirkulasi mini bus byson lebih cepat dibandingkan dengan bus mini hijau dengan selisih 36-40 menit.Tarif kedua moda angkutan untuk pelajar

\section{REFERENSI}

Anonim. (2015). Penelitian Metode

Deskriptif Kualitatif.

www.Kompas.com diakses pada

tanggal 14/11/2016 pada pukul 19.45

WIB.

Habibullah. (2013). Perbandingan Overhand

Throw Dan Sidehand Throw Terhdap

Akurasi Dan Kecepatan Lemparan

Dalam Olahraga Softball. Skripsi,

Universitas Pendidikan Indonesia

Peraturan Menteri Perhubungan Nomor 27

Tahun . (2015). Tentang Standar

Pelayanan Minimal Angkutan Massal

Berbasis Jalan

Peraturan Menteri Perhubungan Nomor 32

Tahun (2016). Tentang

Penyelenggaraan Angkutan Orang

Dengan Kendaraan Bermotor Umum

Tidak Dalam Trayek. kurang dari Rp. 5.000, namun tarif untuk pekerja mini bus byson lebih murah Rp. 2.500 dibandingkan bus mini hijau. kondisi kendaraan baik mini bus byson dan bus mini hijau masih layak jalan akan tetapi mini bus byson lebik banyak menyediakan armada dibandingkan bus mini hijau. Sedangkan fasilitas kesehatan antara kedua angkutan umum tersebut adanya kesamaan tidak tersedianya kotak P3K, palu pemecah kaca, informasi tanggap darurat. Secara keamanan bus mini hijau sudah dilengkapi pegangan tangan untuk berdiri sedangkan mini bus byson tidak tersedia. Untuk fasilitas pintu masuk dan keluar penumpang mini bus byson memiliki pintu yang tertutup ketika kendaraan bergerak sedangkan bus mini hijau tetap terbuka ketika bergerak.

Surat Keputusan Direktorat Jenderal Perhubungan Darat Nomor : SK.687/AJ.206/DRJD/2002 tentang Pedoman Teknis Penyelenggaraan Angkutan Penumpang Umum di Wilayah Perkotaan dalam Trayek Tetap dan Teratur.

Widayanti, Ari. Soeparno. Bhertin Karunia. (2014). Permasalahan dan Pengenbangan Angkutan Umum di kota Surabaya. Jurnal Transportasi Vol. 14 No 1 hal 53-60 
Volume 71, Nomor 1, 1 Juni 2019 